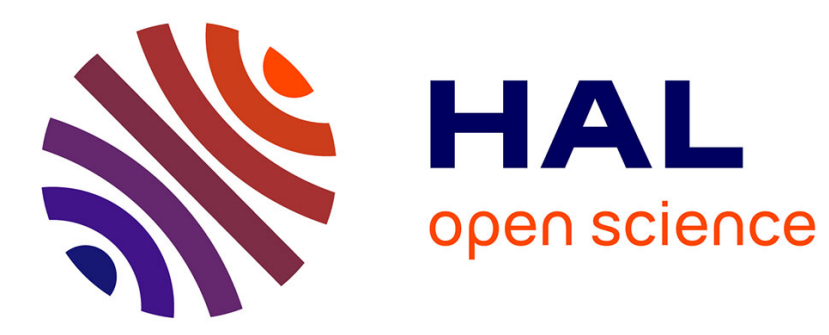

\title{
Two transmembrane Cys residues are involved in 5-HT 4 Receptor dimerization
}

\author{
Magali Berthouze, Lucie Rivail, Alexandre Lucas, Mohammed A Ayoub, \\ Olivier Russo, Sames Sicsic, Rodolphe Fischmeister, Isabelle Berque-Bestel, \\ Ralf Jockers, Frank Lezoualc'H
}

\section{To cite this version:}

Magali Berthouze, Lucie Rivail, Alexandre Lucas, Mohammed A Ayoub, Olivier Russo, et al.. Two transmembrane Cys residues are involved in 5-HT 4 Receptor dimerization. Biochemical and Biophysical Research Communications, 2007, 356 (3), pp.642-647. 10.1016/j.bbrc.2007.03.030 . hal-02942068

\section{HAL Id: hal-02942068 \\ https://hal.science/hal-02942068}

Submitted on 17 Sep 2020

HAL is a multi-disciplinary open access archive for the deposit and dissemination of scientific research documents, whether they are published or not. The documents may come from teaching and research institutions in France or abroad, or from public or private research centers.
L'archive ouverte pluridisciplinaire HAL, est destinée au dépôt et à la diffusion de documents scientifiques de niveau recherche, publiés ou non, émanant des établissements d'enseignement et de recherche français ou étrangers, des laboratoires publics ou privés. 


\section{Two transmembrane Cys residues are involved in $\mathbf{5 - H T _ { 4 }}$ Receptor dimerization}

Magali Berthouze $^{\mathrm{a}, \mathrm{b}, \mathrm{c}}$, Lucie Rivail ${ }^{\mathrm{b}, \mathrm{c}}$, Alexandre Lucas ${ }^{\mathrm{a}, \mathrm{c}}$, Mohammed A. Ayoub $^{\mathrm{d}, \mathrm{e}, \mathrm{f}}$, Olivier Russo ${ }^{\mathrm{b}, \mathrm{c}}$, Sames Sicsic ${ }^{\mathrm{b}, \mathrm{c}}$, Rodolphe Fischmeister ${ }^{\mathrm{a}, \mathrm{c}}$, Isabelle Berque-Bestel ${ }^{\text {b,c }}$, Ralf Jockers ${ }^{\mathrm{d}, \mathrm{e}, \mathrm{f}}$, Frank Lezoualc' $\mathrm{h}^{\mathrm{a}, \mathrm{c}, \text {, }}$

${ }^{a}$ INSERM, U769, Châtenay-Malabry, F-92296 France;

${ }^{\mathrm{b}}$ CNRS, UMR8076, BIOCIS, Reconnaissance Moléculaire et Synthèse, Châtenay-Malabry, F-92296 France;

${ }^{c}$ Univ Paris-Sud, Faculté de Pharmacie, IFR141, Châtenay-Malabry, F-92296 France;

${ }^{\mathrm{d}}$ Institut Cochin, Department of Cell Biology, Paris, F-75014 France; ${ }^{\mathrm{e}}$ INSERM, U567, Paris, F-75014 France;

${ }^{\mathrm{f}}$ Université Paris Descartes, Faculté de médecine René Descartes, CNRS, UMR8104, Paris, F-75014 France

*Corresponding author . Fax: +33146835475

E-mail address: Frank.Lezoualch@u-psud.fr 


\begin{abstract}
The 5- $\mathrm{HT}_{4}$ receptor $\left(5-\mathrm{HT}_{4} \mathrm{R}\right)$ belongs to the $\mathrm{G}$ protein-coupled receptor (GPCR) family and is of considerable interest for the development of new drugs to treat gastrointestinal diseases and memory disorders. The $5-\mathrm{HT}_{4} \mathrm{R}$ exists as a constitutive dimer but its molecular determinants are still unknown. Using co-immunoprecipitation and Bioluminescence Resonance Energy Transfer (BRET) techniques, we show here that 5- $\mathrm{HT}_{4} \mathrm{R}$ homodimerization but not $5-\mathrm{HT}_{4} \mathrm{R}-\beta_{2}$ adrenergic receptor $\left(\beta_{2} \mathrm{AR}\right)$ heterodimerization is largely decreased under reducing conditions suggesting the participation of disulfide bonds in 5- $\mathrm{HT}_{4} \mathrm{R}$ dimerization. Molecular modelling and protein docking experiments identified four cysteine (Cys) residues potentially involved in the dimer interface through intramolecular or intermolecular disulfide bonds. We show that disulfide bridges between, Cys112 and Cys145 located within TM3 and TM4, respectively, are of critical importance for 5-HT 4 R dimer formation. Our data suggest that two disulfide bridges between two transmembrane Cys residues are involved in the dimerization interface of a GPCR.
\end{abstract}

Keywords: Serotonin; BRET; G-protein-coupled receptor; Dimer; Disulfide bridge; Molecular modelling

Abbreviations used: $\beta_{2} \mathrm{AR}, \beta_{2}$ adrenergic receptor, BRET, Bioluminescence Resonance Energy Transfer; Cys, cysteine; ECL, extracellular loop; GPCR, G-protein-coupled receptor; 5- $\mathrm{HT}_{4} \mathrm{R}, 5-\mathrm{HT}_{4}$ receptor; h5- $\mathrm{HT}_{4} \mathrm{R}$, human 5- $\mathrm{HT}_{4}$ receptor; $\mathrm{MT}_{1} \mathrm{R}, \mathrm{MT}_{1}$ melatonin receptor; RLuc, Renilla Luciferase; SDS, sodium dodecyl sulphate; TM, transmembrane domain; $V_{2} R$, $\mathrm{V}_{2}$ vasopressin receptor; WT, wild type; YFP, yellow fluorescent protein. 


\section{Introduction}

The serotonin $5-\mathrm{HT}_{4}$ receptor $\left(5-\mathrm{HT}_{4} \mathrm{R}\right)$ is a G-protein-coupled receptor and may represent a valuable target for the treatment of many human disorders $[1,2]$. In humans, the $5-\mathrm{HT}_{4} \mathrm{R}$ is coded by a single and very complex gene which generates more than eight C-terminal splice variants $[3,4]$. All 5- $\mathrm{HT}_{4} \mathrm{R}$ isoforms share the same ligand binding domain and are positively coupled to adenylyl cyclase. We have recently shown that $5-\mathrm{HT}_{4} \mathrm{R}$ isoforms are present as constitutive dimers and their homo- or heterodimerized forms are independent of their state of activation by ligands [5]. Given the large number of 5-HT $\mathrm{H}_{4} \mathrm{R}$ isoforms which are coexpressed in a same tissue, heterodimerization may represent an extraordinary way to increase the complexity by which this 5-HT receptor subtype mediates its biological effects. It is therefore important to elucidate the molecular determinants involved in $5-\mathrm{HT}_{4} \mathrm{R}$ dimer formation.

Despite intense investigation, the domains critical for GPCR dimerization remain poorly understood [6]. Early studies suggested key roles for both N- and C- terminal elements in homodimeric interactions [6,7]. N-terminal glycosylation may also be important in GPCR heterodimerization as reported for the $\alpha_{2 A^{-}}$and $\beta_{1}$-AR [8]. However, increasing evidence largely based on mutational analysis, individual transmembrane (TM) domain expression and cross-linking experiments now suggests that the TM $\alpha$-helical domains represent the major dimerization interface for both GPCR homodimers and heterodimers [9]. For instance, TM4TM4 and/or TM4/5-TM4/5 contacts appear to be involved in dimer interfaces of the dopamine D2 receptor [10], rhodopsin [11] and the C5a receptors [12]. A peptide corresponding to the sequence of TM6 of $\beta_{2}$-AR was found to reduce $\beta_{2}$-AR dimer formation implying a potential role for this TM domain in dimerization [13].

Although hydrophobic interactions appear to be the main interactions involved in the dimerization interface, several studies have pointed out the importance of covalent bonds in 
dimer formation. For instance, intermolecular disulfide bonds between cysteines (Cys) located at extracellular regions of the amino-terminal domain of the calcium-sensing [14] and the metabotropic glutamate receptors are important for receptor dimerization [15]. More recently, two Cys located in the N-terminus and in the extracellular loop of the angiotensin type 2 receptor have been shown to be critical for homo-oligomerization through intermolecular interaction by disulfide linkage [16].

In the present study, using co-immunoprecipitation and Bioluminescence Resonance Energy Transfer (BRET) techniques, we found that $5-\mathrm{HT}_{4} \mathrm{R}$ constitutive dimerization was largely decreased under reducing conditions. We provide evidence that intracellular disulfide bridges between TM3 and TM4 are specifically involved in the 5- $\mathrm{HT}_{4} \mathrm{R}$ dimerization interface. 


\section{Materials and Methods}

Cell culture and transient transfection. Chinese hamster ovary (CHO) cells and Human embryonic kidney 293 (HEK293) cells were grown in HamsF12 medium and Dulbecco's modified Eagle's medium respectively, supplemented with $10 \%(\mathrm{v} / \mathrm{v})$ foetal calf serum and antibiotics. Transient transfection experiments were performed using the transfection reagent Jet PEI (poly-plus transfection, Illkirch, France) according to the manufacturer's instructions.

Plasmid constructs. The tagged human 5- $\mathrm{HT}_{4(\mathrm{~d})}$ receptor isoform used for immunoprecipitation studies (FLAG-5-HT $\mathrm{F}_{4} \mathrm{R}, \mathrm{HA}-5-\mathrm{HT}_{4} \mathrm{R}$ ) and the 5- $\mathrm{HT}_{4} \mathrm{R}$ fusion proteins used for BRET studies (5-HT $\mathrm{H}_{4} \mathrm{R}-\mathrm{RLuc}$, 5-HT $\mathrm{H}_{4} \mathrm{R}-\mathrm{YFP}$ ) have been previously described [5]. The human $\mathrm{MT}_{1}$ melatonin $(\mathrm{MT} 1 \mathrm{R})$, the $\mathrm{V} 2$ vasopressin $(\mathrm{V} 2 \mathrm{R})$ receptors and the $\beta_{2}$ adrenergic receptor $\left(\beta_{2} \mathrm{AR}\right)$ fused in frame with either RLuc $\left(\mathrm{MT}_{1} \mathrm{R}-\mathrm{RLuc}\right.$, V2R-RLuc, $\beta_{2} \mathrm{AR}-$ RLuc) or YFP (MT $\left.{ }_{1} \mathrm{R}-\mathrm{YFP}, \mathrm{V} 2 \mathrm{R}-\mathrm{YFP}, \beta_{2} \mathrm{AR}-\mathrm{YFP}\right)$ have been previously described [17-19]. Point mutations converting Cys residues into Ala (C93,184A; C267,271A; C112A; C145A; $\mathrm{C} 112,145 \mathrm{~A})$ were individually introduced into the tagged $5-\mathrm{HT}_{4(\mathrm{~d})} \mathrm{R}$ by PCR-based site directed mutagenesis.

Immunoprecipitation and Western blotting. Membrane protein samples prepared as previously described [5], were incubated with anti-Flag agarose beads (M2-Flag beads Sigma) overnight at $4{ }^{\circ} \mathrm{C}$ and then, were washed three times with $5 \mathrm{mM}$ Tris- $\mathrm{HCl} \mathrm{pH}$ 7.4, $2 \mathrm{mM}$ EDTA, $10 \mathrm{mM}$ iodoacetamide and resuspended in 2 fold concentrated Laemmli buffer $(125 \mathrm{mM}$ Tris- $\mathrm{HCl} \mathrm{pH}$ $6.8,4 \%$ sodium dodecyl sulfate (SDS), $20 \%$ glycerol, $0.01 \%$ bromophenol blue) at $95^{\circ} \mathrm{C}$ for 8 min. Immunocomplexes were resolved by $12 \%$ SDS-polyacrylamide gel electrophoresis (PAGE), transferred to a nitrocellulose membrane (Amersham Pharmacia Biotech), and subjected to immunoblotting using a rat monoclonal anti-HA antibody (high affinity clone 
3F10, Roche). Immunoreactive bands were then visualized by the ECL detection kit (Amersham Pharmacia Biotech) on Kodak ML lights films.

BRET assay. BRET experiments were performed as previously described [19]. Briefly, $48 \mathrm{~h}$ after transfection, $\mathrm{CHO}$ or HEK 293 cells expressing $5-\mathrm{HT}_{4} \mathrm{R}$ fusion proteins were detached and washed with PBS. Cell and membrane preparation were distributed in a 96-well optiplate (Packard) in the presence or absence of ligand at $25^{\circ} \mathrm{C}$. Coelenterazine h substrate (Interchim, Montlucon, France) was added at a final concentration of $5 \mu \mathrm{M}$, and readings were performed with a lumino/fluorometer Fusion ${ }^{\mathrm{TM}}$ (Packard) which allows the sequential integration of luminescence signals detected with two filter settings (RLuc filter, $485 \pm 10 \mathrm{~nm}$; YFP filter, $530 \pm 12.5 \mathrm{~nm}$ ). Emission signals at $530 \mathrm{~nm}$ were divided by emission signals at $485 \mathrm{~nm}$. The difference between this emission ratio obtained with co-transfected RLuc and YFP fusions proteins and that obtained with the Luc fusion protein alone was defined as the BRET ratio. Results were expressed in milliBRET units (mBU, with $1 \mathrm{mBU}$ corresponding to the BRET ratio values multiplied by 1000$)$.

Computer Modeling. After manual alignment of the sequence of the $\mathrm{h} 5-\mathrm{HT}_{4} \mathrm{R}$, the threedimensional model of the seven $\mathrm{h} 5-\mathrm{HT}_{4} \mathrm{R}$ TM was built using the bovine rhodopsin crystallographic structure (A-1HZX) as template, in which the position of TM3 was modified (about $17^{\circ}$ rotation around the helix axis) to take into account previous mutagenesis results. After obtaining an energy refined model of the seven $\mathrm{TM}$ of the $\mathrm{h} 5-\mathrm{HT}_{4} \mathrm{R}$, the extra and intracellular loops were then added. This was achieved using the 'homology' loops module, which uses a library of loop templates from the Brookhaven protein data bank (PDB). The details of the different refinement steps have been already described in a previous work [20]. Concerning GRAMM calculations, we have applied the low-resolution docking with a $6.8 \AA$ 
grid step, using the special mode for helix in privileging the hydrophobic interactions. One of the two monomers was rotated with $10^{\circ}$-angle intervals as described in a previous work [21]. Models were built on an «Octane» Silicon Graphics computer, using software from Molecular Simulation Inc. (InsightII, Biopolymer, Homology, Discover). Annealing was performed using the computing facilities of CINES (Centre Informatique National de l’Enseignement Supérieur, Montpellier, France). 


\section{Results and discussion}

\section{Disulfide bonds are involved in $5-\mathrm{HT}_{4} \mathrm{R}$ constitutive dimerization}

To test the possible involvement of disulfide bonds in 5- $\mathrm{HT}_{4} \mathrm{R}$ dimerization, we examined the effect of the reducing agent dithiothreitol (DTT) on 5- $\mathrm{HT}_{4} \mathrm{R}$ dimerization using the BRET technique $[18,19]$. The assay relies on the observation that the degree of physical proximity between molecules can be assessed in living cells by the level of energy transfer occurring between the energy donor RLuc and a fluorescent acceptor, YFP [19]. Fig. 1 shows that the BRET signal was markedly decreased in CHO and HEK cells treated with DTT $(20 \mathrm{mM})$ for 10 min. Longer exposure to DTT did not further decrease the BRET signal (data not shown). In addition, we found that DTT decreased the BRET signal in a concentration dependent manner with a maximum effect at $20 \mathrm{mM}$ (Fig. 1C). This reducing agent did not change the intensity of the luminescence and fluorescence signals indicating that DTT has no significant effect on Rluc activity and YFP fluorescence (data not shown). Accordingly, we showed by immuprecipitation assays that $5-\mathrm{HT}_{4} \mathrm{R}$ dimeric species were converted to monomeric forms under reducing conditions (+DTT) (Fig. 3B, lanes 2,3). Our findings suggest that covalent interactions are involved in the $5-\mathrm{HT}_{4} \mathrm{R}$ dimerization interface.

\section{5-HT 4 R and $V_{2} R$ but not $M T_{1} R$ dimers are sensitive to $D T T$}

To determine the specificity of DTT on $5-\mathrm{HT}_{4} \mathrm{R}$ dimerization, we analysed its effect on two other GPCRs, the $\mathrm{MT}_{1}$ melatonin receptor (MT1R) and $\mathrm{V}_{2}$ vasopressine receptor $\left(\mathrm{V}_{2} \mathrm{R}\right)$. In agreement with a previous study, which suggests the involvement of hydrophobic interactions in $\mathrm{MT}_{1} \mathrm{R}$ dimer formation [19], $\mathrm{MT}_{1} \mathrm{R}$ dimerization state was not sensitive to DTT as determined by BRET (Fig. 2). Conversely, $\mathrm{V}_{2} \mathrm{R}$ transfected cells showed a decrease in BRET signal in the presence of DTT, although the effect of DTT was lower than with $5-\mathrm{HT}_{4} \mathrm{R}$ (Fig. 2). Thus, as previously observed by immunoblot [17], DTT induces a partial loss of $\mathrm{V}_{2} \mathrm{R}$ 
dimerization. Altogether these data suggest that disulfide bonds are specifically involved in the dimerization of $5-\mathrm{HT}_{4} \mathrm{R}$.

\section{Role of intramembrane Cys in 5- $\mathrm{HT}_{4} \mathrm{R}$ dimerization}

We then attempted to identify the molecular determinants involved in $5-\mathrm{HT}_{4} \mathrm{R}$ dimerization. Intramolecular disulfide bonds between extracellular loops (ECLs) have been shown to be critical not only for GPCR structure/function [22] but also for receptor dimerization [23]. For the 5- $\mathrm{HT}_{4} \mathrm{R}$, two extracellular Cys, C93 and C184, are known to form a disulfide bridge between the extracellular part of TM3 and ECL2 [24] (supplemental Fig. S1). However, we found by immunoblot and BRET experiments that the double mutation C93A,C184A did not influence the sensitivity of the receptor to DTT, excluding the involvement of those extracellular Cys in dimer formation (data not shown). This observation is consistent with the recent observation of Baneres and colleagues [24] who showed no effect of Cys 93 and Cys 184 on the overall structural arrangement of the $5-\mathrm{HT}_{4} \mathrm{R}$.

To identify other Cys residues potentially involved in receptor-receptor interactions, we used the molecular model of the 5- $\mathrm{HT}_{4} \mathrm{R}$ [24]. This three-dimensional model was built using the bovine rhodopsin crystallographic structure (A-1HZX) [25] as template for the seven transmembrane domains and the "homology" loops module for the extra- and intra-cellular loops. During the refinement steps of the model, we took into account mutagenesis results $[20,26]$ and performed docking experiments of different $5-\mathrm{HT}_{4}$ ligands as described in Materials and Methods. All Cys residues located both in the TM domains and in the different loops were visualized. We identified four Cys within the TM which could be involved in the dimerization interface (supplemental Fig. S1, Fig. 3A). Indeed, C267 and C271 located in TM6, C112 in TM3, and C145 in TM4, are all oriented towards the outside of the receptor in our model (Fig. 3A). 
Next, we took into account recent protein/protein docking experiments based on GRAMM Software for investigating potential dimer arrangements [21]. This software considers the proteins as rigid entities and realized an exhaustive research in the three-dimensional space using translations and rotations; then it evaluates the surface complementarities, penalizes covering and orders the obtained results. From the molecular model of the $5-\mathrm{HT}_{4} \mathrm{R}$ using the optimized parameters as defined in Materials and Methods, GRAMM generated 100 structures. Two main structures of dimer emerged with $40 \%$ of 2-4/2-4 complexes including TM2 and 4 in their dimer interface and 40\% of 4-6/4-6 complexes including TM4 and TM6. Altogether these data led us to focus our research on C112, C145, C267 and C271, for their potential involvement in $5-\mathrm{HT}_{4} \mathrm{R}$ dimerization interface through the formation of disulfide bridges between TM3 and TM4, or TM6 (Fig. 3A).

To test this hypothesis, two double Cys mutants (C112A,C145A and C267A,C271A) were constructed and their effect on $5-\mathrm{HT}_{4} \mathrm{R}$ constitutive dimerization under denaturing or nondenaturing conditions was analysed. Co-immunoprecipitation studies showed that the double mutation located in TM6 (C267A,C271A) had no effect on dimer formation as compared to the WT form (Fig. 3B, lanes 2 and 4). C267A,C271A behaved as the WT 5-HT 4 R since DTT induced the dissociation of dimers and the appearance of monomeric forms of $5-\mathrm{HT}_{4} \mathrm{R}$ (Fig. $3 \mathrm{~B}$, lanes 3 and 5). In contrast, the $\mathrm{C} 112 \mathrm{~A}, \mathrm{C} 145 \mathrm{~A}$ mutant strongly reduced the quantity of 5$\mathrm{HT}_{4} \mathrm{R}$ dimers (Fig. 3B, lane 6) that were still sensitive to DTT (Fig. 3B, lane 7). Consistent with these findings, comparable BRET values were obtained in cells expressing the C267A,C271A mutant or the WT form with or without DTT (Fig. 4A) indicating that residues C267 and C271 are not responsible for the effect of DTT on 5- $\mathrm{HT}_{4}$ receptor dimerization. In contrast, the BRET signal of the $\mathrm{C} 112 \mathrm{~A}, \mathrm{C} 145 \mathrm{~A}$ mutant in the absence of DTT was very similar to that observed for the WT in the presence of DTT suggesting that this mutant adopts a receptor conformation which resembles the WT conformation under reducing conditions 
(Fig. 4A). These results strongly suggest that residues C112 and C145 participate in the stabilisation of 5- $\mathrm{HT}_{4} \mathrm{R}$ dimers through the formation of disulfide bonds.

At first glance our data contrast with previous studies since covalent bonds usually occur in the extracellular part of membrane proteins. However, as shown for the electron transporter DsbD [27] intramembrane environment may favour the formation of disulfide bonds in membrane proteins. Moreover, the localization of C112 and C145 on TM3 and TM4 reinforces the involvement of these TM domains in dimer arrangements. This is in agreement with the concept that similar dimerization motifs in TM domains such as (AGSTP)XXX(GMS) sequence types play a key role in receptor dimerization and can be used as a consensus motif to identify potential dimerization sequences [28]. In the $5-\mathrm{HT}_{4} \mathrm{R}$, a (A) $\mathrm{XXX}(\mathrm{G})$ sequence is present in TM4 and is oriented towards the outside of the receptor in a convenient position to allow dimer contacts. Altogether this indicates that TM4 is an important molecular determinant of $5-\mathrm{HT}_{4} \mathrm{R}$ dimerisation that involves covalent (disulfide bridge) and hydrophobic interactions.

\section{DTT does not influence 5-HT 4 R- $\beta_{2}$ adrenergic receptor $\left(\beta_{2} \mathrm{AR}\right)$ heterodimerization}

Having shown in a previous study that $\beta_{2} \mathrm{AR}$ and $5-\mathrm{HT}_{4} \mathrm{R}$ were able to form constitutive heterodimers [5], we next investigated whether $\mathrm{C} 112, \mathrm{C} 145$ of the $5-\mathrm{HT}_{4} \mathrm{R}$ may be involved in $\beta_{2} \mathrm{AR}$ and $5-\mathrm{HT}_{4} \mathrm{R}$ heterodimerization. We found that constitutive $\beta_{2} \mathrm{AR}$ dimers were not influenced by DTT (Fig. 4B). In addition, a significant energy transfer was observed on membrane preparation of $\mathrm{CHO}$ cells transfected with $\beta_{2} \mathrm{AR}-\mathrm{RLuc}$ and C112A,C145A-YFP. DTT did not influence $\beta_{2} \mathrm{AR}$ and C112A,C145A heterodimers suggesting that disulfide bonds are not involved in the $\beta_{2} \mathrm{AR} / 5-\mathrm{HT}_{4} \mathrm{R}$ dimerization interface (Fig. 4B). 
In conclusion, we report for the first time that intramembrane Cys residues are involved in the dimerization interface of a GPCR. Further molecular modelling experiments are needed in order to design new drugs which are able to influence the dimerization process. 


\section{Acknowledgments}

Magali Berthouze was supported by a pre-doctoral grant from the Ministère de la Recherche et de l'Enseignement Supérieur and the Fondation pour la Recherche Médicale. We thank Monique Gastineau, Mireille Giner and Jean-Luc Guillaume for their technical assistance. 


\section{References}

[1] M. Langlois, R. Fischmeister, 5- $\mathrm{HT}_{4}$ receptor ligands: applications and new prospects, J. Med. Chem. 46 (2003) 319-344.

[2] M. Maillet, S.J. Robert, F. Lezoualc'h, New insights into serotonin 5-HT 4 receptors:a novel therapeutic target for Alzheimer's disease?, Curr. Alzheimer Res. 1 (2004) 79-85.

[3] J. Bockaert, S. Claeysen, V. Compan, A. Dumuis, 5-HT 4 receptors, Curr Drug. Targets CNS Neurol. Disord., 3 (2004) 39-51.

[4] M. Maillet, M. Gastineau, P. Bochet, M.L. Asselin-Labat, E. Morel, J. N. Laverrière, A.M. Lompré, R. Fischmeister, F. Lezoualc'h, Functional studies of the 5'-untranslated region of human 5-HT 4 receptor mRNA, Biochem. J. 387 (2005) 463-471.

[5] M. Berthouze, M. Ayoub, O. Russo, L. Rivail, S. Sicsic, R. Fischmeister, I. BerqueBestel, R. Jockers, F. Lezoualc'h, Constitutive dimerization of human serotonin $5-\mathrm{HT}_{4}$ receptors in living cells, FEBS Lett. 579 (2005) 2973-2980.

[6] M. Filizola, H. Weinstein, Structural models for dimerization of G-protein coupled receptors: the opioid receptor homodimers, Biopolymers 66 (2002) 317-325.

[7] S. Abdalla, E. Zaki, H. Lother, U. Quitterer, Involvement of the amino terminus of the $\mathrm{B}(2)$ receptor in agonist-induced receptor dimerization, J. Biol. Chem. 274 (1999) 26079-26084.

[8] J. Xu, J. He, A.M. Castleberry, S. Balasubramanian, A.G. Lau, R.A. Hall, Heterodimerization of alpha 2A- and $\beta 1$-adrenergic receptors, J. Biol. Chem. 278 (2003) 10770-10777. 
[9] S. Bulenger, S. Marullo, M. Bouvier, Emerging role of homo- and heterodimerization in G-protein-coupled receptor biosynthesis and maturation, Trends Pharmacol. Sci. 26 (2005) 131-137.

[10] W. Guo, L. Shi, J.A. Javitch, The fourth transmembrane segment forms the interface of the dopamine D2 receptor homodimer, J. Biol. Chem. 278 (2003) 4385-4388.

[11] D. Fotiadis, A. Engel, High-resolution imaging of bacteriorhodopsin by atomic force microscopy, Methods Mol. Biol. 242 (2004) 291-303.

[12] J.M. Klco, T.B. Lassere, T.J. Baranski, C5a receptor oligomerization. I. Disulfide trapping reveals oligomers and potential contact surfaces in a $G$ protein-coupled receptor, J. Biol. Chem. 278 (2003) 35345-35353.

[13] T.E. Hebert, S. Moffett, J.P. Morello, T. P. Loisel, D.G. Bichet, C. Barret, M. Bouvier, A peptide derived from a beta2-adrenergic receptor transmembrane domain inhibits both receptor dimerization and activation, J. Biol. Chem. 271 (1996) 16384-16392.

[14] Z. Zhang, S. Sun, S.J.Quinn, E.M. Brown, M. Bai, The extracellular calcium-sensing receptor dimerizes through multiple types of intermolecular interactions, J. Biol. Chem. 276 (2001) 5316-5322.

[15] Ray, K. and Hauschild, B. C. (2000) Cys-140 is critical for metabotropic glutamate receptor-1 dimerization. J. Biol. Chem. 275, 34245-34251.

[16] S. Miura, S.S. Karnik, K. Saku, Constitutively active homo-oligomeric angiotensin II type 2 receptor induces cell signaling independent of receptor conformation and ligand stimulation, J. Biol. Chem. 280 (2005)18237-18244.

[17] X. Zhu, J. Wess, Truncated V2 vasopressin receptors as negative regulators of wild-type 
V2 receptor function, Biochemistry 37 (1998) 15773-15784.

[18] S. Angers, A. Salahpour, E. Joly, S. Hilairet, D. Chelsky, M. Dennis, M. Bouvier, Detection of beta 2-adrenergic receptor dimerization in living cells using bioluminescence resonance energy transfer (BRET), Proc. Natl. Acad. Sci. U S A 97 (2000) 3684-3689.

[19] M.A. Ayoub, C. Couturier, E. Lucas-Meunier, S. Angers, P. Fossier, M. Bouvier, R. Jockers, Monitoring of ligand-independent dimerization and ligand-induced conformational changes of melatonin receptors in living cells by bioluminescence resonance energy transfer, J. Biol. Chem. 277 (2002) 21522-21528.

[20] L. Rivail, M. Giner, G. Gastineau, M. Berthouze, J.L. Soulier, R. Fischmeister, F. Lezoualc'h, B. Maigret, S. Sicsic, I. Berque-Bestel, New insights into the human 5-HT 4 receptor binding site: exploration of a hydrophobic pocket, Br. J. Pharmacol. 143 (2004) $361-370$.

[21] J.L. Soulier, O. Russo, M. Giner, L. Rivail, M. Berthouze, S. Ongeri, B. Maigret, R. Fischmeister, F. Lezoualc'h, S. Sicsic, I. Berque-Bestel, Design and Synthesis of Specific Probes for Human 5-HT 4 Receptor Dimerization Studies, J. Med. Chem. 48 (2005) 6220-6228.

[22] S.S. Karnik, C. Gogonea, S. Patil, Y. Saad, T. Takezako, Activation of G-proteincoupled receptors: a common molecular mechanism, Trends Endocrinol. Metab. 14 (2003) 431-437.

[23] F. Y. Zeng, J. Wess, Identification and molecular characterization of m3 muscarinic receptor dimers, J. Biol. Chem. 274 (1999)19487-19497.

[24] J.L. Baneres, D. Mesnier, A. Martin, L. Joubert, A. Dumuis, J. Bockaert, Molecular 
characterization of a purified 5- $\mathrm{HT}_{4}$ receptor: a structural basis for drug efficacy, J. Biol. Chem. 280 (2005) 20253-20260.

[25] K. Palczewski, T. Kumasaka, T. Hori, C.A. Behnke, H. Motoshima, B.A. Fox, I. Le Trong, D.C. Teller, T. Okada, R.E. Stenkamp, M. Yamamoto, M. Miyano, Crystal structure of rhodopsin: A G protein-coupled receptor, Science 289 (2000) 739-745.

[26] J. Mialet, Y. Dahmoune, F. Lezoualc'h, I. Berque-Bestel, P. Eftekhari, J. Hoebeke, S. Sicsic, M. Langlois, R. Fischmeister, Exploration of the ligand binding site of the human $5-\mathrm{HT}_{4}$ receptor by site-directed mutagenesis and molecular modelling, Br. $\mathrm{J}$. Pharmacol. 130 (2000) 527-538.

[27] F. Katzen, J. Beckwith, Role and location of the unusual redox-active cysteines in the hydrophobic domain of the transmembrane electron transporter DsbD, Proc. Natl. Acad. Sci. U. S. A 100 (2003)10471-10476

[28] M.C. Overton, S. Chinault, K.J. Blumer, Oligomerization, biogenesis, and signaling is promoted by a glycophorin A-like dimerization motif in transmembrane domain 1 of a yeast G protein-coupled receptor, J. Biol. Chem. 278 (2003) 49369-49377. 


\section{Figure legends}

Figure 1. Effect of DTT on 5-HT 4 R dimerization in living cells. Membrane preparations from CHO (A) and HEK293 (B) cells co-expressing the 5-HT 4 R-RLuc and the 5-HT 4 R-YFP at a 1:1 ratio, were incubated or not with DTT $(20 \mathrm{mM})$ for $10 \mathrm{~min}$. Coelenterazine $(5 \mu \mathrm{M})$ was then added and light emission acquisition was performed in a luminometer using RLuc and YFP filter settings. Results are means \pm S.E.M. of at least four independent experiments performed in duplicate. (C) Effect of increasing concentrations of DTT on 5-HT 4 dimerization. HEK293 cells were transfected as above and membrane preparations were treated with different concentrations of DTT and the BRET signal was determined as in (A) and (B). Results are means \pm S.E.M. of triplicate in one experiment performed.

Figure 2. Comparative effect of DTT on $5-H_{T} R$, MT1R and V2R dimerization. Membrane preparation from $\mathrm{CHO}$ cells coexpressing, 5-HT $\mathrm{R}-\mathrm{RLuc}$ and $5-\mathrm{HT}_{4} \mathrm{R}-\mathrm{YFP}$, $\mathrm{MT}_{1} \mathrm{R}$-RLuc and the $\mathrm{MT}_{1} \mathrm{R}$-YFP, or $\mathrm{V}_{2} \mathrm{R}$-RLuc and the $\mathrm{V}_{2} \mathrm{R}$-YFP were treated with $20 \mathrm{mM}$ DTT and then the BRET signal was measured.

Figure 3. Dimerization properties of the double mutants C267A,C271A and C112A,C145A. A). Model of the 5- $\mathrm{HT}_{4} \mathrm{R}$ based on the bovine rhodopsin crystallographic structure. Over view (left panel) and side view (right panel) and of the TM parts which contain C112 (TM3), C145 (TM4), C271 and C267 (TM6) are shown. The seven TM are colored in magenta, the Cys residues are colored in yellow for the sulphur atom and cyan for the hydrogen atom. B) Analysis of the effect of DTT effect on the C267A,C267A and the C112A,C145A mutants by co-immunoprecipitation. Membrane preparation of cells coexpressing the HA-5-HT ${ }_{4} \mathrm{R}$ and the FLAG-5-HT 4 R, the FLAG-C267A,C271A and the HA- 
C267A,C271A, the FLAG-C112A,C145A and the HA-C112A,C145A or the empty vector (mock) were immunoprecipited with the anti-FLAG antibody. The immunoprecipited complexes were then treated or not with DTT $(20 \mathrm{mM})$, resolved by non-reducing $12 \%$ SDSPAGE and immunoblotted with the anti-HA antibody. Under non-reducing conditions, the intensity of dimeric bands were identical between the WT 5-HT $\mathrm{H}_{4}$ and the C267A,C271A (lanes 2, 4). A strong decrease in dimer formation was observed for the mutant C112A,C145A receptor compared to the WT form (lanes 2, 6). In the presence of DTT (20 mM), a band corresponding to the monomeric size of the receptor was detected for the two mutants (lanes $5,7)$. The immunoblot shown is representative of at least three independent experiments.

\section{Figure 4. Effects of DTT on C267A,C271A and C112,C145 dimer formation and}

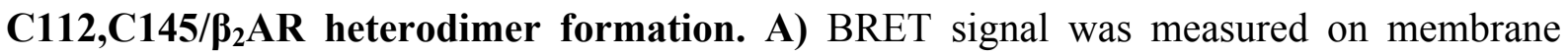
preparation from $\mathrm{CHO}$ cells cotransfected at a 1:1 ratio, with the 5-HT $\mathrm{T}_{4} \mathrm{R}-\mathrm{RLuc}$ and the 5$\mathrm{HT}_{4} \mathrm{R}-\mathrm{YFP}$, the C267A,C271A-RLuc and the C267A,C271A-YFP or the C112A,C145ARLuc and the C112A,C145A-YFP. B) Membrane preparation from CHO cells transfected with 5-HT ${ }_{4} \mathrm{R}-\mathrm{RLuc}$ and the 5-HT ${ }_{4} \mathrm{R}-\mathrm{YFP}$, the $\beta_{2} \mathrm{AR}-\mathrm{RLuc}$ and the $\beta_{2} \mathrm{AR}-\mathrm{YFP}$, or the $\beta_{2} \mathrm{AR}-$ RLuc and C112A,C145A-YFP were treated or not with 20 mM DTT and energy transfer was then determined as described in Materials and Methods. Results expressed as percentage of control are means \pm S.E.M. of three independent experiments performed in duplicate. 
A

CHO cells

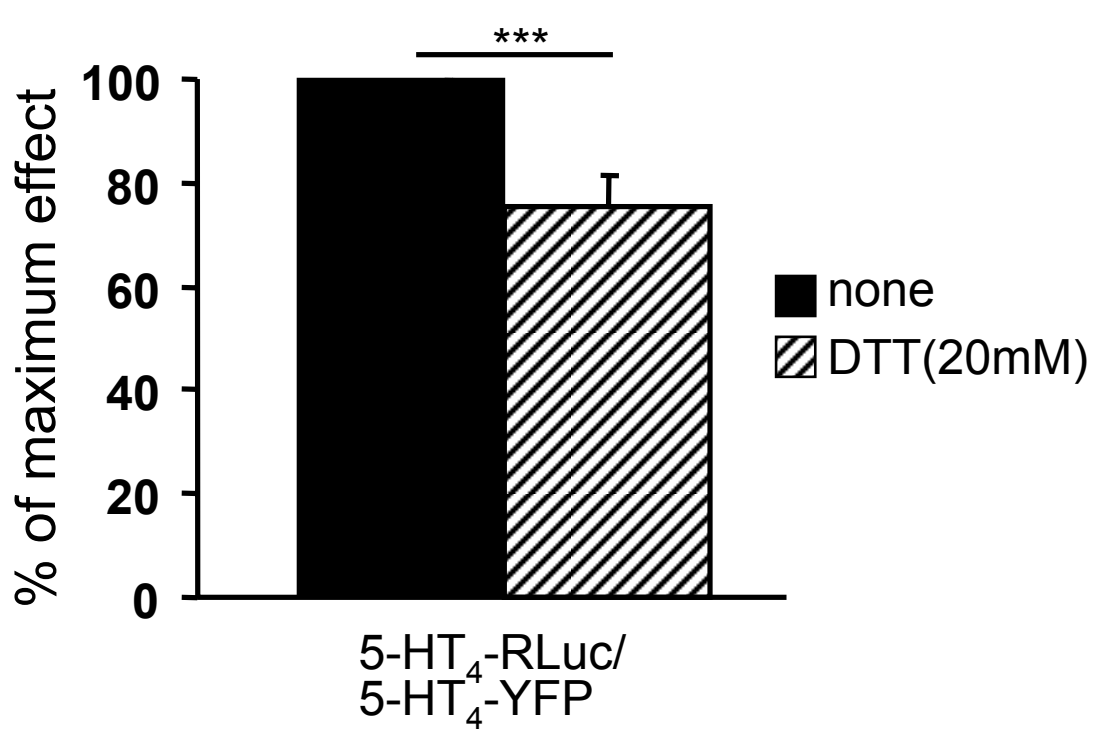

B

HEK293 cells

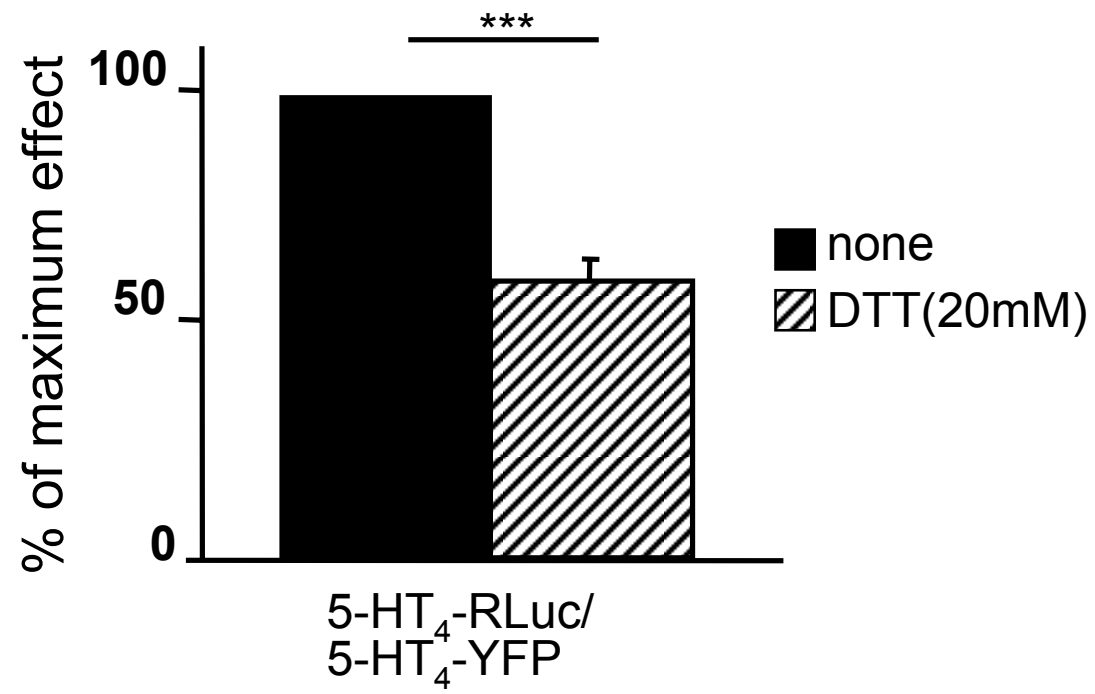

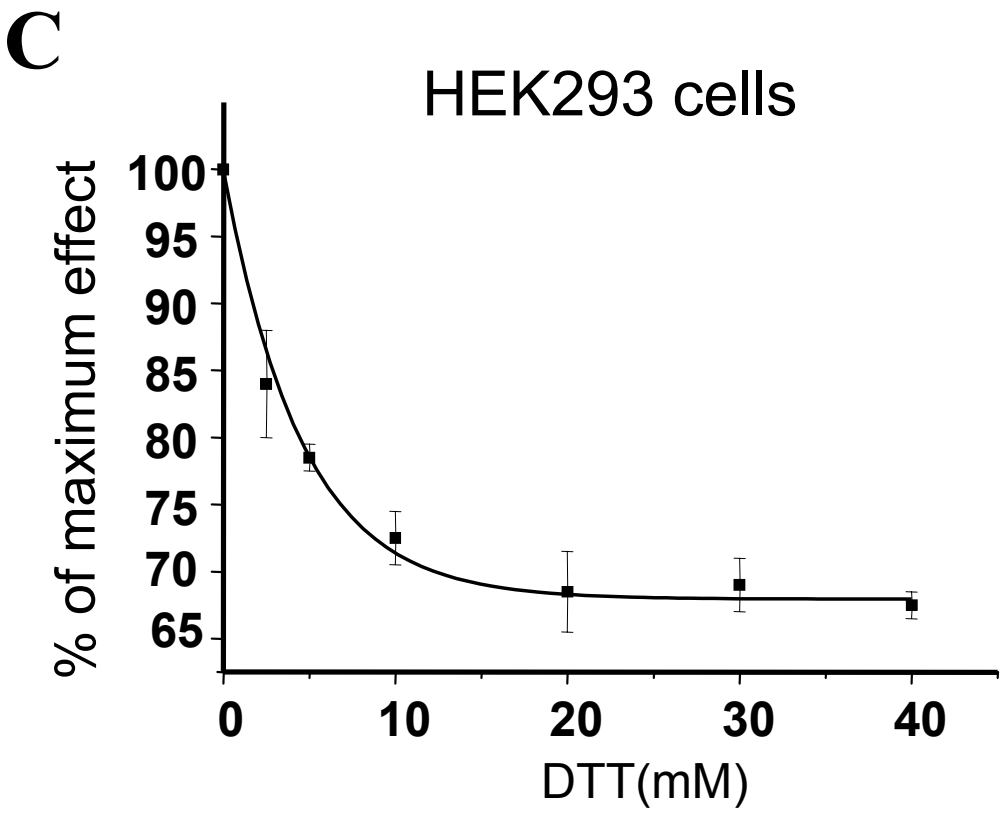




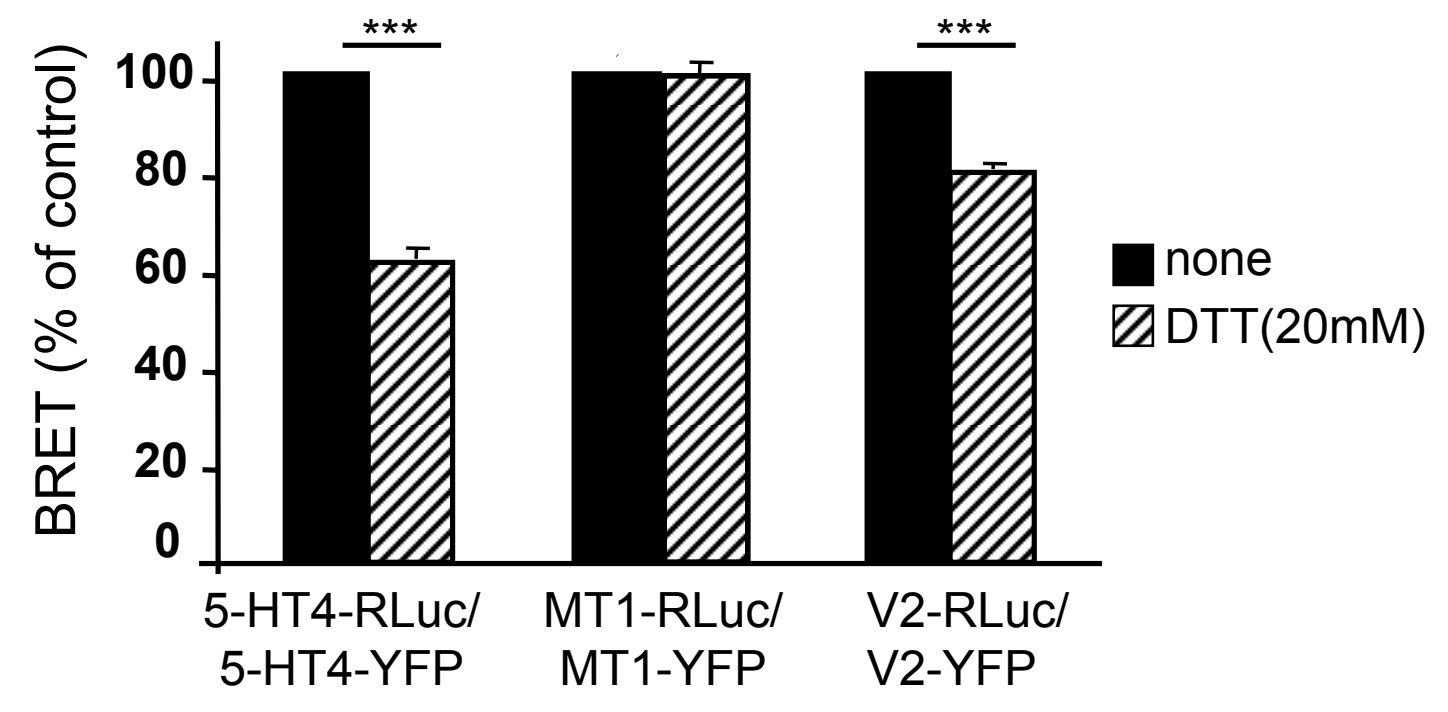

Figure 2 

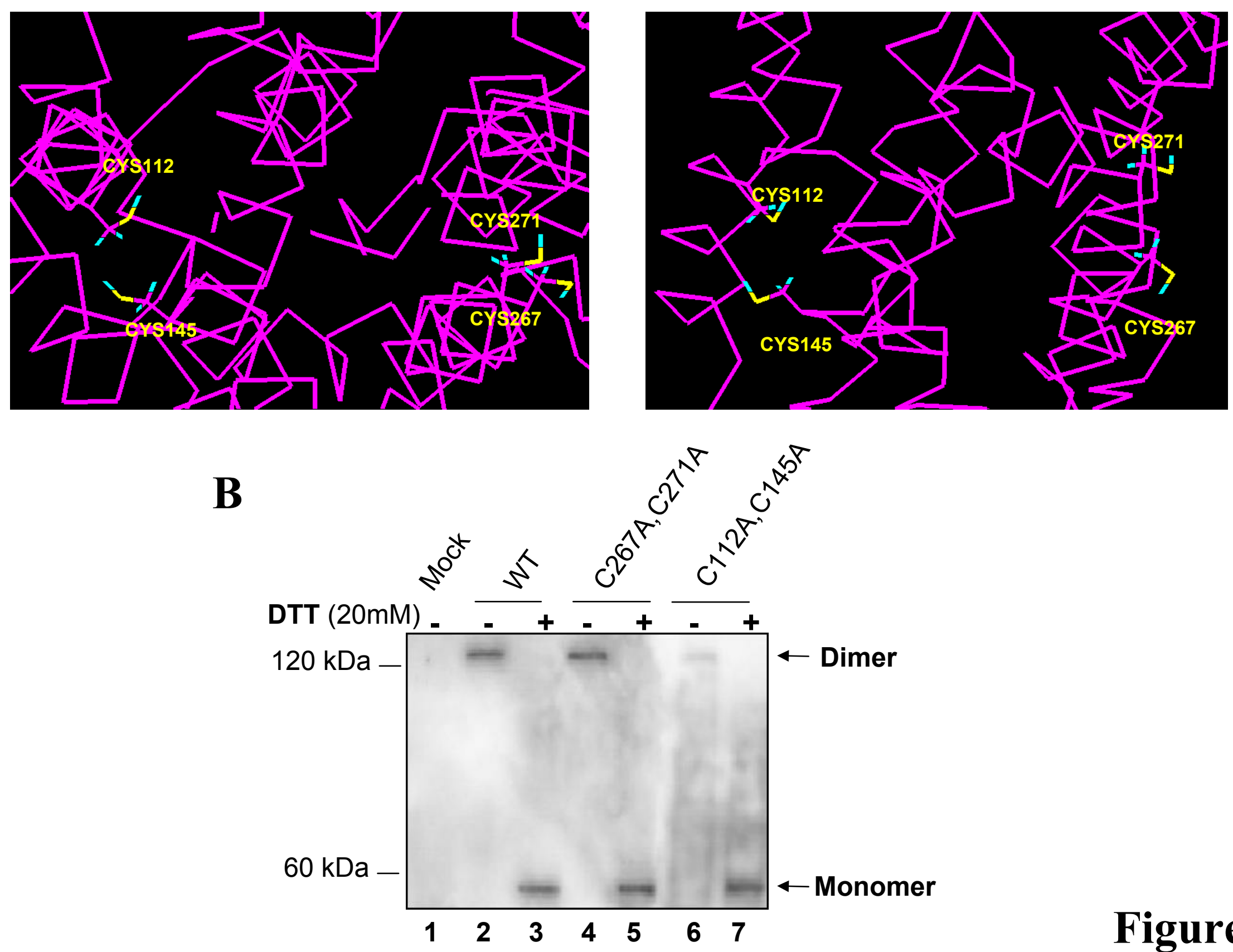

Figure 3 
A

B
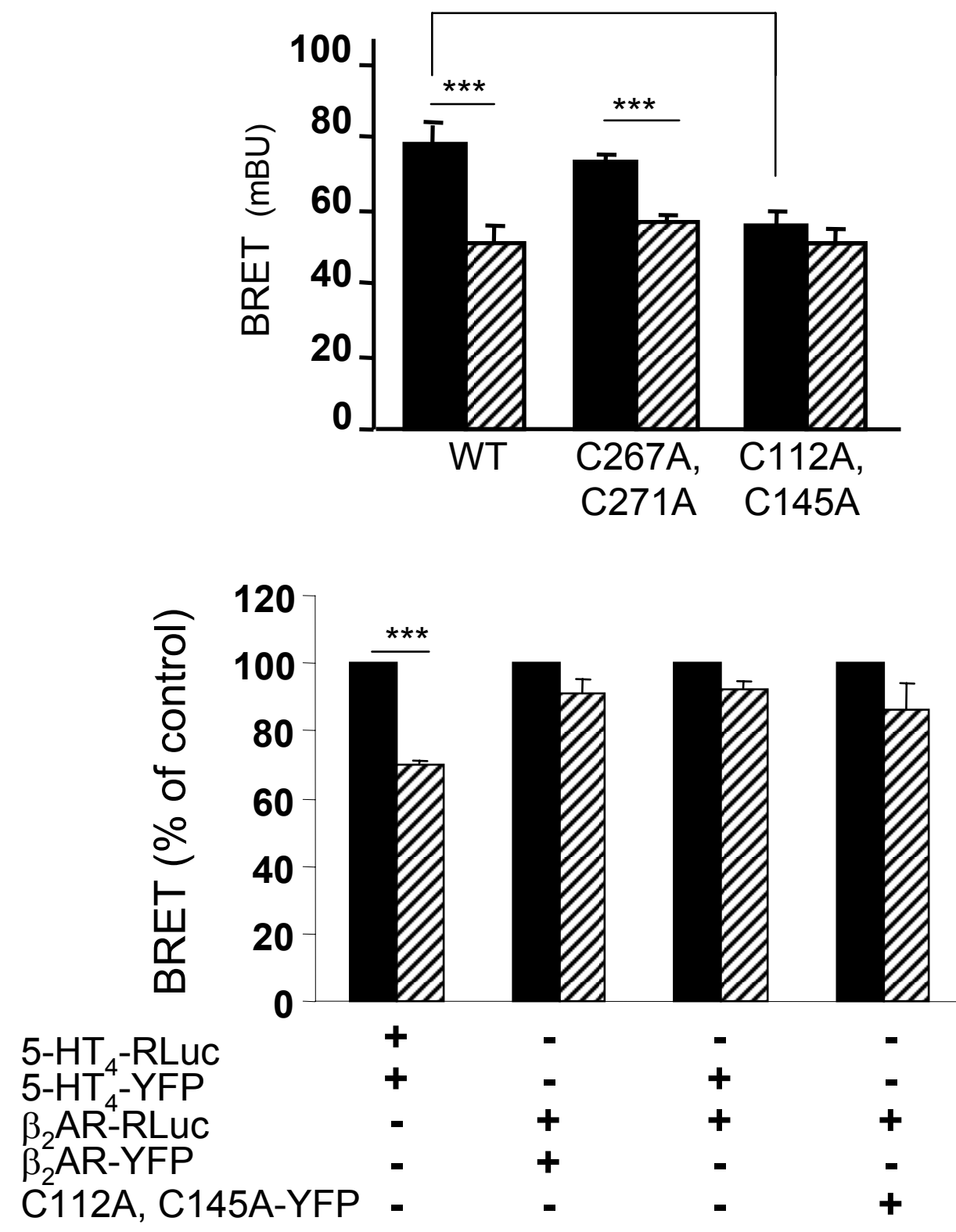

none

छDTT(20mM) none

ØDTT(20mM) 